\title{
Stereochemical preference toward oncotarget: Design, synthesis and in vitro anticancer evaluation of diastereomeric $\beta$-lactams
}

\author{
Fabián Olazarán-Santibáñez ${ }^{1,2}$, Debasish Bandyopadhyay ${ }^{1}$ Pilar Carranza-Rosales ${ }^{3}$, \\ Gildardo Rivera ${ }^{4}$, Isaías Balderas-Rentería ${ }^{2}$ \\ ${ }^{1}$ Department of Chemistry, The University of Texas-Rio Grande Valley, Edinburg, Texas, 78539, USA \\ ${ }^{2}$ Universidad Autonoma de Nuevo Leon, Facultad de Ciencias Químicas, Ciudad Universitaria, San Nicolás de los Garza, \\ Nuevo León, 64451, México \\ ${ }^{3}$ Centro de Investigación Biomédica del Noreste, Instituto Mexicano del Seguro Social, Monterrey, Nuevo León, 64700, \\ México \\ ${ }^{4}$ Centro de Biotecnología Genómica, Instituto Politécnico Nacional, Reynosa, Tamaulipas, 88710, México \\ Correspondence to: Debasish Bandyopadhyay, email: debasish.bandyopadhyay@utrgv.edu \\ Isaías Balderas-Rentería, email: isaias.balderasrn@uanl.edu.mx
}

Keywords: $\beta$-Lactam, diastereoisomer, molecular docking, $\beta$-Tubulin, cancer

Received: March 06, $2017 \quad$ Accepted: April 17, $2017 \quad$ Published: May 22, 2017

Copyright: Olazarán-Santibáñez et al. This is an open-access article distributed under the terms of the Creative Commons Attribution License (CC-BY), which permits unrestricted use, distribution, and reproduction in any medium, provided the original author and source are credited.

\section{ABSTRACT}

Purpose: In the battle against cancer discovery of new and novel chemotherapeutic agent demands extreme obligation. Development of anticancer compounds with higher potency and reduced side-effects is timely and challenging.

Experimental Design: A small series of fourteen diastereomeric $\beta$-lactams (seven pairs) were synthesized through multi-step process exploring [2+2] ketene-imine cycloaddition as the key step. Comparative stereochemical preferences were studied through computational docking and validated by in vitro evaluation. $\beta$-tubulin was considered as possible molecular target and in vitro anticancer evaluation was conducted against SiHa, B16F10, K562 and Chang cell lines. Caspase-3 activation assay and hematoxylin/eosin staining of the cells were also accomplished.

Results: Better docking scores of the cis- over the trans- $\beta$-lactams indicated favorable $\beta$-lactam- $\beta$-tubulin interactions in cis-geometry. In vitro (IC I0 $_{50}$ ) evaluation confirmed better anticancer activity of the cis-diastereoisomers. Apoptosis-induced cell death was supported by caspase-3 activation study. A cis- $\beta$-lactam $[( \pm)$-Cis3-amino-1-phenyl-4-(p-tolyl) azetidin-2-one, 6C] was found to be more active (in vitro) than the marketed natural drug colchicine against SiHa and B16F10 (six times higher potency) cell lines. Reduced toxicity (compared to colchicine) in Chang cells confirmed better site-selectivity (accordingly less side-effects) of 6C than colchicine. Aside from $6 \mathrm{C}$, most of the reported molecules demonstrated good to strong in vitro anticancer activity against SiHa and B16F10 cancer cell lines.

Conclusions: Stereochemical preferences of the cis- $\beta$-lactams over their transcounterparts, toward the molecular target $\beta$-tubulin, was confirmed by docking studies and in vitro anticancer evaluation. Apoptosis was identified as the cause of cell death. The lead $6 \mathrm{C}$ exhibited higher potency and selectivity than the marketed drug colchicine both in silico as well as in vitro.

\section{INTRODUCTION}

Cancer is one of the leading causes of death globally and is expected to increase approximately $70 \%$ in the next two decades [1]. Although cancer is not a new disease, the description of cancer is found in several ancient literatures since $3000 \mathrm{BC}$, yet it is one of the primary reasons of death till today and subsequently one of the 
worse enemies of modern civilization. While radiotherapy, immunotherapy and surgical treatment play significant role in the battle against cancer but chemotherapy, either by own or in combination with other therapies, is still the most widely used strategy for the treatment of cancer. Moreover, several types of cancer have been developed drug resistance for which no effective drugs are available in the market $[2,3]$. Therefore, it is important to develop new and selective anticancer drugs with higher potency and reduced side effects.

Since the discovery of penicillin in 1928, the four-membered cyclic amide (frequently known as 2 -azetidinone or $\beta$-lactam) possesses the central position in drug discovery research, in particular, to treat a wide range of microbial infection. Notably, the $\beta$-lactam pharmacophore is present in a huge number of molecules (both natural and synthetic) that dominate worldwide the market of antibiotics [4-6]. In contrary, many compounds (natural, synthetic or semi-synthetic) are being used in cancer chemotherapy but the use of $\beta$-lactam derivatives in cancer chemotherapy is still unknown. This might be due to the reason that the research on $\beta$-lactam as anticancer agents is comparatively new and not been broadly explored. In fact, the anticancer activity of diversely substituted trans- $\beta$-lactams have been reported [7-15] to some extent and after careful search of available literatures we did not find a single example targeted to comparative computational and biological studies of anticancer potential of cis- and trans- $\beta$-lactams. To the best of our knowledge, this is the first report that systematically correlates the diastereoselectivity (cis- and trans-) of $\beta$-lactams with anticancer activity.

\section{RESULTS}

\section{Chemistry}

In the present study Staudinger [2+2] ketene-imine cycloaddition reaction [16] was performed extensively for the diastereomeric synthesis of diversely substituted 3 -phthalimido $\beta$-lactams. In the subsequent step, the deprotection of the primary amine was carried out by converting the 3-phthalimido $\beta$-lactams to 3 -aminoazetidin-2-ones with ethylene diamine in dry ethanol (Scheme 1).

A total of $14 \beta$-lactam derivatives (seven pairs of diastereomers) have been synthesized (Supplementary Table 1) through multi-step process (Scheme 1) exploring $[2+2]$ ketene-imine cycloaddition as the key step. Although the compounds were synthesized through multi-step process and purified by repeated column chromatography yet good to excellent yields were isolated each cases. The structure and druglikeness of each molecule are shown in Table 1.

The structure of the 2-azetidinone derivatives were elucidated by extensive spectroscopic analyses as follows:

( \pm -Cis-3-amino-1,4-bis(4-methoxyphenyl) azetidin2-one (1C). Brown solid (78\%); Formula Weight: 298.34; MP $102{ }^{\circ} \mathrm{C}$; IR (KBr) 3401, 3012, 1715,1507, 1246, 826 $\mathrm{cm}^{-1} ;{ }^{1} \mathrm{H}$ NMR (600 MHz, $\left.\mathrm{CDCl}_{3}\right) \delta 7.32(\mathrm{~d}, 2 \mathrm{H}), 7.20(\mathrm{~d}$, $2 \mathrm{H}), 6.95(\mathrm{~d}, 2 \mathrm{H}), 6.81(\mathrm{~d}, 2 \mathrm{H}), 5.21(\mathrm{~d}, J=5.0 \mathrm{~Hz}, 1 \mathrm{H})$, $4.57(\mathrm{~d}, J=5.0 \mathrm{~Hz}, 1 \mathrm{H}), 3.82$ (s, 3H), 3.77 (s, 3H). Formula: $\mathrm{C}_{16} \mathrm{H}_{16} \mathrm{~N}_{2} \mathrm{O}_{2}$; Anal. calcd for: $\mathrm{C}, 71.6 \%$; H, 6.0\%; N, 10.4\%.

$( \pm)$-Cis-3-amino-4-(4-methoxyphenyl)-1-phenylazetidin-2-one (2C). Brown solid (88\%); Formula Weight: 268.32; MP $106{ }^{\circ} \mathrm{C}$; IR (KBr) 3341, 2928,1728, 1499, $1248,746 \mathrm{~cm}^{-1} ;{ }^{1} \mathrm{H} \mathrm{NMR}\left(600 \mathrm{MHz}, \mathrm{CDCl}_{3}\right) \delta 7.29-7.08$ $(\mathrm{m}, 2 \mathrm{H}), 7.03-6.93(\mathrm{~m}, 2 \mathrm{H}), 6.86-6.77(\mathrm{~m}, 4 \mathrm{H}), 4.56$ $(\mathrm{d}, J=2.2 \mathrm{~Hz}, 1 \mathrm{H}), 3.96(\mathrm{~d}, J=2.3 \mathrm{~Hz}, 1 \mathrm{H}), 3.71(\mathrm{~s}, 3 \mathrm{H})$ $1.93(\mathrm{~s}, 2 \mathrm{H})$. Anal. calcd for: $\mathrm{C}_{17} \mathrm{H}_{18} \mathrm{~N}_{2} \mathrm{O}_{3}$ Composition: $\mathrm{C}$, $68.4 \%$; H, 6.1\%; N, 9.4\%.

$( \pm)$-Cis-3-amino-4-(3,4-dimethoxyphenyl)-1-(4methoxyphenyl) azetidin-2-one (3C). Brown solid (68\%); Formula Weight: 328.36; MP $92{ }^{\circ} \mathrm{C}$; IR (KBr) 3379, 2956, $1738,1509,1237,828 \mathrm{~cm}^{-1}$; ${ }^{1} \mathrm{H} \mathrm{NMR}\left(600 \mathrm{MHz}, \mathrm{CDCl}_{3}\right.$ ) $\delta 6.83-6.80(\mathrm{~m}, 2 \mathrm{H}), 6.79-6.76(\mathrm{~m}, 4 \mathrm{H}), 6.75-6.74$ $(\mathrm{m}, 9 \mathrm{H}), 5.10(\mathrm{~d}, J=5.4 \mathrm{~Hz}, 1 \mathrm{H}), 4.48(\mathrm{~d}, J=5.4 \mathrm{~Hz}$, $1 \mathrm{H}), 3.80$ - $3.68(\mathrm{~m}, 9 \mathrm{H})$. Anal. calcd for: $\mathrm{C}_{18} \mathrm{H}_{20} \mathrm{~N}_{2} \mathrm{O}_{4}$; Composition: C, 65.8\%; H, 6.1\%; N, 8.5\%.

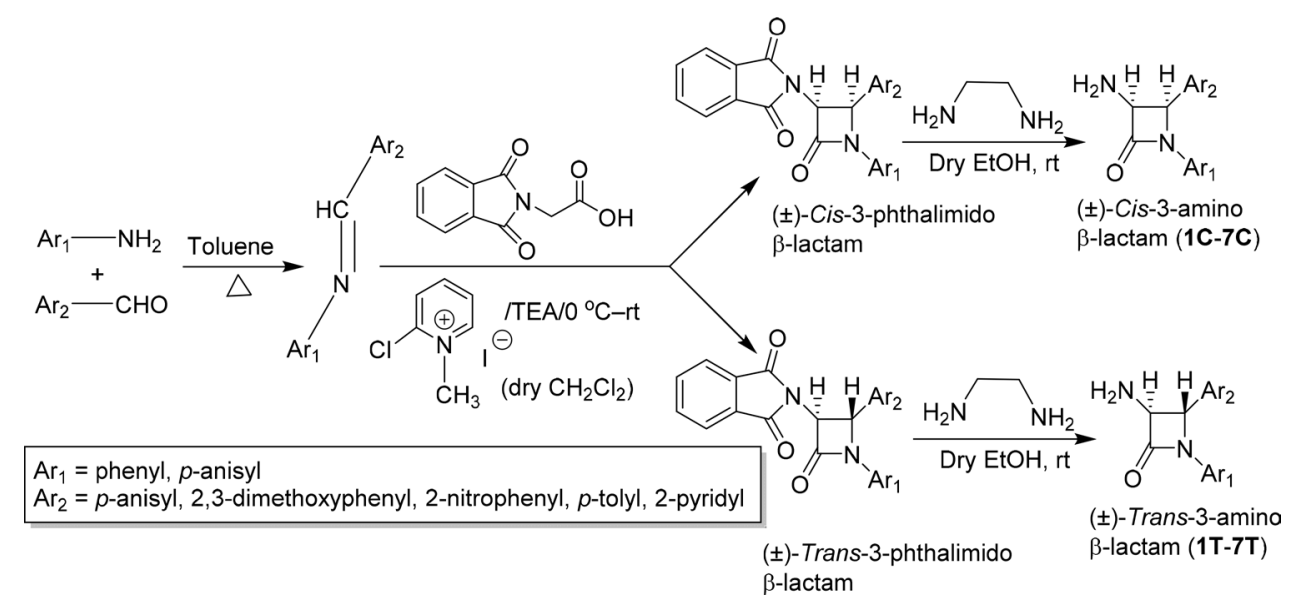

Scheme 1: Diastereoselective synthesis of $\beta$-lactams via [2+2] ketene-imine cycloaddition reaction. 
Table 1: Molecular docking of the $\beta$-lactam derivatives on the binding sites of the $\beta$-tubulin

\begin{tabular}{|l|c|c|c|}
\hline \multicolumn{1}{c}{ Code } & $\begin{array}{c}\text { Docking score (kcal/mol) } \\
\text { Colchicine site }\end{array}$ & $\begin{array}{c}\text { Docking score (kcal/mol) Taxol } \\
\text { site }\end{array}$ & $\begin{array}{c}\text { Docking score (kcal/mol) } \\
\text { Vinca site }\end{array}$ \\
\hline 1C & -6.6 & -6.7 & -6.7 \\
\hline 2C & -7.0 & -6.4 & -6.1 \\
\hline 3C & -6.8 & -6.4 & -6.2 \\
\hline $4 \mathrm{C}$ & -7.2 & -6.3 & -6.8 \\
\hline $5 \mathrm{C}$ & -7.2 & -6.7 & -6.7 \\
\hline 6C & $-\mathbf{7 . 6}$ & -7.0 & -6.9 \\
\hline 7C & -6.5 & -6.2 & -6.0 \\
\hline 1T & -6.6 & -6.7 & -6.6 \\
\hline 2T & -7.2 & -6.7 & -6.9 \\
\hline $3 \mathrm{~T}$ & -6.8 & -6.6 & -6.6 \\
\hline 4T & -7.3 & -6.9 & -6.9 \\
\hline $5 \mathrm{~T}$ & -7.4 & -6.9 & -7.3 \\
\hline $6 \mathrm{~T}$ & -7.4 & -6.8 & -7.0 \\
\hline 7T & -6.7 & -6.3 & -6.5 \\
\hline Colchicine & -7.4 & --- & --- \\
\hline Paclitaxel & --- & $-\mathbf{9 . 8}$ & --- \\
\hline Vinblastine & --- & --- & $-\mathbf{1 0 . 0}$ \\
\hline
\end{tabular}

( \pm -Cis-3-amino-1-(4-methoxyphenyl)-4-(2nitrophenyl) azetidin-2-one (4C). Brown solid (52\%); Formula Weight: 313.31 ; MP $185^{\circ} \mathrm{C}$; IR (KBr) 3325,2952 , $1747,1509,1248,822 \mathrm{~cm}^{-1} ;{ }^{1} \mathrm{H}$ NMR $\left(600 \mathrm{MHz}, \mathrm{CDCl}_{3}\right) \delta$ $8.08-8.03(\mathrm{~m}, 3 \mathrm{H}), 7.79-7.76(\mathrm{~m}, 3 \mathrm{H}), 7.75-7.70(\mathrm{~m}$, $1 \mathrm{H}), 7.70-7.66(\mathrm{~m}, 6 \mathrm{H}), 7.62-7.56(\mathrm{~m}, 6 \mathrm{H}), 6.08(\mathrm{~d}$, $J=5.8 \mathrm{~Hz}, 5 \mathrm{H}), 6.05(\mathrm{~d}, J=5.8 \mathrm{~Hz}, 5 \mathrm{H}), 5.35-5.27$ $(\mathrm{m}, 1 \mathrm{H}), 3.83(\mathrm{~s}, 3 \mathrm{H})$. Anal. calcd for: $\mathrm{C}_{16} \mathrm{H}_{15} \mathrm{~N}_{3} \mathrm{O}_{4}$; Composition: C 61.3\%, H 4.8\%, N 13.4\%.

( \pm )-Cis-3-amino-1-(4-methoxyphenyl)-4-( $p$-tolyl) azetidin-2-one (5C). Brown solid (80\%); Formula Weight: 282.34; MP $103{ }^{\circ} \mathrm{C}$; IR (KBr)3359, 2934, 1730, 1510, 1245 , $823 \mathrm{~cm}^{-1} ;{ }^{1} \mathrm{H}$ NMR $\left(600 \mathrm{MHz}, \mathrm{CDCl}_{3}\right) \delta 7.24-7.20(\mathrm{~m}$, $6 \mathrm{H}), 7.14(\mathrm{~d}, J=8.1 \mathrm{~Hz}, 3 \mathrm{H}), 7.07(\mathrm{~d}, J=8.1 \mathrm{~Hz}, 1 \mathrm{H})$, $6.74-6.70(\mathrm{~m}, 7 \mathrm{H}), 5.13(\mathrm{~d}, J=5.4 \mathrm{~Hz}, 3 \mathrm{H}), 4.50(\mathrm{~d}$, $J=5.5 \mathrm{~Hz}, 3 \mathrm{H}), 3.68(\mathrm{~s}, 3 \mathrm{H}) 2.36-2.32(\mathrm{~m}, 3 \mathrm{H})$. Anal. calcd for: $\mathrm{C}_{17} \mathrm{H}_{18} \mathrm{~N}_{2} \mathrm{O}_{2}$; Composition: $\mathrm{C}, 72.3 \% ; \mathrm{H}, 6.4 \% ; \mathrm{N}, 9.9 \%$.

( \pm -Cis-3-amino-1-phenyl-4-( $p$-tolyl) azetidin-2one (6C). Brown solid (84\%); Formula Weight: 252.31; MP $130{ }^{\circ} \mathrm{C}$; IR (KBr) 3356, 2925, 1731, 1502, $748 \mathrm{~cm}^{-1}$; ${ }^{1} \mathrm{H}$ NMR $\left(600 \mathrm{MHz}, \mathrm{CDCl}_{3}\right) \delta 7.73(\mathrm{dt}, J=13.6,6.9 \mathrm{~Hz}$, $2 \mathrm{H}), 7.71-7.65(\mathrm{~m}, 2 \mathrm{H}), 7.43-7.35(\mathrm{~m}, 2 \mathrm{H}), 7.26$ (ddd, $J=8.1,5.0,2.4 \mathrm{~Hz}, 2 \mathrm{H}), 6.94-6.87(\mathrm{~m}, 4 \mathrm{H}), 5.68(\mathrm{~d}$, $J=5.5 \mathrm{~Hz}, 1 \mathrm{H}), 5.46(\mathrm{~d}, J=5.5 \mathrm{~Hz}, 1 \mathrm{H}), 3.82(\mathrm{~s}, 3 \mathrm{H})$. Anal. calcd for: $\mathrm{C}_{16} \mathrm{H}_{16} \mathrm{~N}_{2} \mathrm{O}$; Composition: $\mathrm{C}, 76.2 \%$; $\mathrm{H}$, $6.4 \% ; \mathrm{N}, 11.1 \%$.

( \pm -Cis-3-amino-1-(4-methoxyphenyl)-4-(2-pyridyl) azetidin-2-one (7C). Brown solid (51\%); Formula Weight: 269.30; MP $120^{\circ} \mathrm{C}$; IR (KBr) 3373, 2952, 1721, 1509 , $1239,828 \mathrm{~cm}^{-1} ;{ }^{1} \mathrm{H}$ NMR $\left(600 \mathrm{MHz}, \mathrm{CDCl}_{3}\right) \delta 8.71(\mathrm{~d}$, $J=4.0 \mathrm{~Hz}, 3 \mathrm{H}), 7.74(\mathrm{td}, J=7.7,1.6 \mathrm{~Hz}, 3 \mathrm{H}), 7.33$ (d,
$J=7.7 \mathrm{~Hz}, 4 \mathrm{H}), 7.31-7.27(\mathrm{~m}, 13 \mathrm{H}), 6.82(\mathrm{~d}, J=9.1 \mathrm{~Hz}$, $6 \mathrm{H}), 5.32(\mathrm{~d}, J=5.4 \mathrm{~Hz}, 3 \mathrm{H}), 4.76(\mathrm{~d}, J=5.5 \mathrm{~Hz}, 3 \mathrm{H})$, $3.77(\mathrm{~s}, 3 \mathrm{H})$. Anal. calcd for: $\mathrm{C}_{15} \mathrm{H}_{15} \mathrm{~N}_{3} \mathrm{O}_{2}$; Composition: $\mathrm{C}$, $66.9 \%$; H, 5.6\%; N, $15.6 \%$.

$( \pm)$-Trans-3-amino-1,4-bis(4-methoxyphenyl) azetidin-2-one (1T). Brown solid (71\%); Formula Weight: 268.32; MP $96{ }^{\circ} \mathrm{C}$; IR (KBr) 3341, 2953, 1724,1510, 1245 , $823 \mathrm{~cm}^{-1} ;{ }^{1} \mathrm{H}$ NMR $\left(600 \mathrm{MHz}, \mathrm{CDCl}_{3}\right) \delta 7.19(\mathrm{~d}, 2 \mathrm{H}), 7.14$ (d, 2H), $6.81(\mathrm{~d}, 2 \mathrm{H}), 6.69(\mathrm{~d}, 2 \mathrm{H}), 4.57(\mathrm{~d}, J=1.6 \mathrm{~Hz}$, $1 \mathrm{H}), 3.96(\mathrm{~d}, J=1.7 \mathrm{~Hz}, 1 \mathrm{H}), 3.72(\mathrm{~s}, 3 \mathrm{H}), 3.66(\mathrm{~s}, 3 \mathrm{H})$. Anal. calcd for: $\mathrm{C}_{16} \mathrm{H}_{16} \mathrm{~N}_{2} \mathrm{O}_{2}$; Composition: $\mathrm{C}, 71.6 \%$; $\mathrm{H}$, $6.0 \% ; \mathrm{N}, 10.4 \%$.

( \pm -Trans-3-amino-4-(4-methoxyphenyl)-1-phenylazetidin-2-one (2T). Brown solid (72\%); Formula Weight: 298.34; MP $102{ }^{\circ} \mathrm{C}$; IR (KBr) 3342, 3065,1730, 1513, 1249 , $747 \mathrm{~cm}^{-1} ;{ }^{1} \mathrm{H}$ NMR $\left(600 \mathrm{MHz}, \mathrm{CDCl}_{3}\right) \delta 7.29-7.08(\mathrm{~m}$, $4 \mathrm{H}), 7.03(\mathrm{t}, 1 \mathrm{H}), 6.86(\mathrm{~d}, 4 \mathrm{H}), 4.56(\mathrm{~d}, J=2.2 \mathrm{~Hz}, 1 \mathrm{H}), 3.96$ (d, $J=2.3 \mathrm{~Hz}, 1 \mathrm{H}), 3.71(\mathrm{~s}, 3 \mathrm{H}) 1.84(\mathrm{~s}, 2 \mathrm{H})$. Anal. calcd for: $\mathrm{C}_{17} \mathrm{H}_{18} \mathrm{~N}_{2} \mathrm{O}_{3}$ Composition: $\mathrm{C}, 68.4 \% ; \mathrm{H}, 6.1 \% ; \mathrm{N}, 9.4 \%$.

$( \pm)$-Trans-3-amino-4-(3,4-dimethoxyphenyl)-1-(4methoxyphenyl) azetidin-2-one (3T). Brown solid (93\%); Formula Weight: 328.36; MP $104^{\circ} \mathrm{C}$; IR (KBr) 3301, 3001, $1733,1508,1237,877 \mathrm{~cm}^{-1} ;{ }^{1} \mathrm{H}$ NMR $\left(600 \mathrm{MHz}, \mathrm{CDCl}_{3}\right) \delta$ $7.32(\mathrm{~d}, 13 \mathrm{H}), 7.25(\mathrm{~d}, 9 \mathrm{H}), 6.91(\mathrm{~d}, 12 \mathrm{H}), 6.87(\mathrm{~d}, 6 \mathrm{H}), 6.85-$ $6.83(\mathrm{~m}, 10 \mathrm{H}), 6.81(\mathrm{~d}, 13 \mathrm{H}), 6.76(\mathrm{~s}, 1 \mathrm{H}), 4.61(\mathrm{~d}, J=1.7 \mathrm{~Hz}$, $5 \mathrm{H}), 4.07(\mathrm{~d}, J=1.7 \mathrm{~Hz}, 7 \mathrm{H}), 3.89-3.77$ (m, 9H). Anal. calcd for: $\mathrm{C}_{18} \mathrm{H}_{20} \mathrm{~N}_{2} \mathrm{O}_{4}$; Composition: C, 65.8\%; H, 6.1\%; N, 8.5\%.

( \pm -Trans-3-amino-1-(4-methoxyphenyl)-4-(2nitrophenyl) azetidin-2-one (4T). Brown solid (28\%); Formula Weight: 313.31 ; MP $195{ }^{\circ} \mathrm{C}$; $\mathrm{IR}(\mathrm{KBr}) 3282,3064$, $1745,1509,1243,860 \mathrm{~cm}^{-1} ;{ }^{1} \mathrm{H}$ NMR $\left(600 \mathrm{MHz}, \mathrm{CDCl}_{3}\right) \delta$ 
$7.17-7.13(\mathrm{~m}, 6 \mathrm{H}), 7.09$ (d, $J=7.7 \mathrm{~Hz}, 7 \mathrm{H}), 6.72-6.67$ (m, 3H), 4.89 (s, 6H), 4.84 (d, $J=2.0 \mathrm{~Hz}, 3 \mathrm{H}), 4.55$ (d, $J=2.0 \mathrm{~Hz}, 1 \mathrm{H}), 3.66(\mathrm{~s}, 3 \mathrm{H})$. Anal. calcd for: $\mathrm{C}_{16} \mathrm{H}_{15} \mathrm{~N}_{3} \mathrm{O}_{4}$; Composition: C 61.3\%, H 4.8\%, N 13.4\%.

$( \pm)$-Trans-3-amino-1-(4-methoxyphenyl)-4-( $p$-tolyl) azetidin-2-one (5T). Brown solid (95\%); Formula Weight: 282.34; MP $110^{\circ} \mathrm{C}$; IR (KBr) 3294, 2952, 1730, 1509, 1242, $824 \mathrm{~cm}^{-1} ;{ }^{1} \mathrm{H} \mathrm{NMR}\left(600 \mathrm{MHz}, \mathrm{CDCl}_{3}\right) \delta 7.23-7.18(\mathrm{~m}, 6 \mathrm{H})$, $7.15(\mathrm{~m}, 2 \mathrm{H}), 7.10(\mathrm{~d}, J=7.9 \mathrm{~Hz}, 13 \mathrm{H}), 7.06(\mathrm{~d}, J=8.1 \mathrm{~Hz}$, $3 \mathrm{H}), 6.74-6.68(\mathrm{~m}, 1 \mathrm{H}), 4.52(\mathrm{~d}, J=2.1 \mathrm{~Hz}, 1 \mathrm{H}), 3.93(\mathrm{~d}$, $J=2.1 \mathrm{~Hz}, 1 \mathrm{H}), 3.66(\mathrm{~s}, 3 \mathrm{H}) 2.36-2.32(\mathrm{~m}, 3 \mathrm{H})$. Anal. calcd for: $\mathrm{C}_{17} \mathrm{H}_{18} \mathrm{~N}_{2} \mathrm{O}_{2}$; Composition: C, 72.3\%; H 6.4\%; N, 9.9\%.

$( \pm)$-Trans-3-amino-1-phenyl-4-( $p$-tolyl)azetidin-2one (6T). Brown solid (62\%); Formula Weight: 252.31; MP $135^{\circ} \mathrm{C}$; IR (KBr) 3354, 3028, 1731, 1501, $792 \mathrm{~cm}^{-1}$; ${ }^{1} \mathrm{H}$ NMR $\left(600 \mathrm{MHz}, \mathrm{CDCl}_{3}\right) \delta 7.21(\mathrm{dt}, J=11.6,3.1 \mathrm{~Hz}$, $2 \mathrm{H}), 7.18-7.14(\mathrm{~m}, 4 \mathrm{H}), 7.11(\mathrm{~d}, J=7.9 \mathrm{~Hz}, 2 \mathrm{H}), 7.00$ $-6.94(\mathrm{~m}, 1 \mathrm{H}), 4.57$ (d, $J=2.2 \mathrm{~Hz}, 1 \mathrm{H}), 3.96$ (d, $J=2.3$ $\mathrm{Hz}, 1 \mathrm{H}), 2.32-2.23(\mathrm{~m}, 3 \mathrm{H}), 1.78(\mathrm{~s}, 3 \mathrm{H})$. Anal. calcd for: $\mathrm{C}_{16} \mathrm{H}_{16} \mathrm{~N}_{2} \mathrm{O}$; Composition: C, 76.2\%; H, 6.4\%; N, $11.1 \%$.

$( \pm)$-Trans-3-amino-1-(4-methoxyphenyl)-4-(2-

pyridyl)azetidin-2-one (7T). Brown solid (60\%); Formula Weight: 269.30; MP $114{ }^{\circ} \mathrm{C}$; IR (KBr) 3371, 2953, 1729, $1510,1294,820 \mathrm{~cm}^{-1} ;{ }^{1} \mathrm{H}$ NMR $\left(600 \mathrm{MHz}, \mathrm{CDCl}_{3}\right) \delta 8.71$ $(\mathrm{d}, J=4.0 \mathrm{~Hz}, 3 \mathrm{H}), 7.74(\mathrm{td}, J=7.7,1.6 \mathrm{~Hz}, 3 \mathrm{H}), 7.33$ (d, $J=7.7 \mathrm{~Hz}, 4 \mathrm{H}), 7.31-7.27(\mathrm{~m}, 13 \mathrm{H}), 6.82(\mathrm{~d}, J=9.1 \mathrm{~Hz}$, $6 \mathrm{H}), 5.32(\mathrm{~d}, J=2.3 \mathrm{~Hz}, 3 \mathrm{H}), 4.76(\mathrm{~d}, J=2.3 \mathrm{~Hz}, 3 \mathrm{H})$, $3.77(\mathrm{~s}, 3 \mathrm{H})$. Anal. calcd for: $\mathrm{C}_{15} \mathrm{H}_{15} \mathrm{~N}_{3} \mathrm{O}_{2}$; Composition: $\mathrm{C}$, $66.9 \% ; \mathrm{H}, 5.6 \%$; N, $15.6 \%$.

\section{Molecular docking}

By means of computational chemistry, a molecular docking assay was performed targeting the protein $\beta$-tubulin. The drug-protein interaction of all the fourteen 3-amino-azetidin-2-one derivatives (1C-7C and 1T-7T) was studied on the three available and known binding sites (vinca, taxol and colchicine) of $\beta$-tubulin [17]. Vinblastine, taxol (paclitaxel) and colchicine were considered as the control molecules and the free energy (Kcal/mol) for each compound was calculated (Table 1).

The docking interactions of ( \pm -Cis-3-amino-1phenyl-4-( $p$-tolyl)azetidin-one (6C) is shown in Figure 1.

\section{Cytotoxic activity}

The $\mathrm{IC}_{50}$ values of the fourteen 2-azetidinone derivatives (seven pair of diastereomers) were calculated from the concentrations of 10 to $0.312 \mu \mathrm{M}$ for each compound (triplicate) against $\mathrm{SiHa}$ (human cervical), B16F10 (murine melanoma), K562 (human immortalized myelogenous leukemia) and Chang cell lines. $\mathrm{IC}_{50}$ values of the azetidin-2-ones are shown in Table 2.

The cytotoxic effect of the compound $6 \mathrm{C}$ in $\mathrm{SiHa}$ and Chang cells has been studied (Figure 2). In a Hematoxylin/Eosin staining sample where monolayers of SiHa (a) and Chang (d) cells in the untreated control groups (negative control) showed the characteristic morphology of normal cell cultures, irregularly shaped, well-defined junctions and nucleus-cytoplasm ratio was preserved. In $\mathrm{SiHa}$ cells incubated with $1 \mu \mathrm{M}$ of the compound $6 \mathrm{C}$ (b) morphological alterations was observed; mainly characterized by loss of cytoplasm and decrease in the size of nuclei (arrows). Moreover, in the incubated Chang cells, $1 \mu \mathrm{M}$ concentration of the compound $6 \mathrm{C}(\mathrm{e})$, the damage could be characterized by the appearance of multiple intracytoplasmic vacuoles $(*)$. Treatment with taxol $(20 \mathrm{mg} / \mathrm{mL})$ induced severe



Figure 1: Molecular docking of the compound 6C on $\beta$-tubulin molecule. 
Table 2: $\mathrm{IC}_{50}$ values $(\mu \mathrm{M})$ of $\beta$-lactam derivatives against SiHa, B16F10, K562 and Chang cell lines (triplicate)

\begin{tabular}{|c|c|c|c|c|}
\hline Compound code & SiHa & B16F10 & K562 & Chang \\
\hline $1 \mathrm{~T}$ & $7.17 \pm 0.3$ & $5.16 \pm 0.5$ & $>10.00$ & $7.91 \pm 0.4$ \\
\hline $2 \mathrm{~T}$ & $7.14 \pm 0.5$ & $7.63 \pm 0.4$ & $>10.00$ & $>10.00$ \\
\hline $3 \mathrm{~T}$ & $>10.00$ & $>10.00$ & $>10.00$ & $>10.00$ \\
\hline $4 \mathrm{~T}$ & $8.12 \pm 0.4$ & $>10.00$ & $>10.00$ & $>10.00$ \\
\hline $5 \mathrm{~T}$ & $7.79 \pm 0.5$ & $7.14 \pm 0.6$ & $>10.00$ & $>10.00$ \\
\hline $6 \mathrm{~T}$ & $4.79 \pm 0.6$ & $5.79 \pm 0.4$ & $>10.00$ & $>10.00$ \\
\hline $7 \mathrm{~T}$ & $>10.00$ & $>10.00$ & $>10.00$ & $>10.00$ \\
\hline $1 \mathrm{C}$ & $4.21 \pm 0.4$ & $3.33 \pm 0.3$ & $>10.00$ & $6.21 \pm 0.5$ \\
\hline $2 \mathrm{C}$ & $6.20 \pm 0.6$ & $1.71 \pm 0.3$ & $>10.00$ & $8.03 \pm 0.5$ \\
\hline $3 \mathrm{C}$ & $5.10 \pm 0.4$ & $3.91 \pm 0.3$ & $6.14 \pm 0.4$ & $9.32 \pm 0.6$ \\
\hline $4 \mathrm{C}$ & $7.28 \pm 0.5$ & $5.91 \pm 0.6$ & $>10.00$ & $7.37 \pm 0.4$ \\
\hline $5 \mathrm{C}$ & $4.03 \pm 0.5$ & $2.09 \pm 0.1$ & $>10.00$ & $7.01 \pm 0.1$ \\
\hline $6 \mathrm{C}$ & $2.34 \pm 0.2$ & $0.70 \pm 0.1$ & $>10.00$ & $6.89 \pm 0.3$ \\
\hline $7 \mathrm{C}$ & $8.43 \pm 0.3$ & $>10.00$ & $6.86 \pm 0.4$ & $5.49 \pm 0.4$ \\
\hline Colchicine & $2.5 \pm 0.5$ & $4.1 \pm 0.1$ & $1.3 \pm 0.1$ & $0.52 \pm 0.1$ \\
\hline Paclitaxel & $364 \pm 310 *$ & $9.57 \pm 0.2$ & $4.80 \pm 0.4^{*}$ & $0.068 \pm 0.02$ \\
\hline Vinblastine & $10.88 \pm 0.8$ & $55 \pm 28 *$ & $0.006 \pm 0.0$ & $\mathrm{ND} * *$ \\
\hline
\end{tabular}

*ng/mL; **Not determined.

cell damage in SiHa cells (c), where nuclear membrane pucker (creaser) (n), perinuclear vacuoles (pv), loss of cytoplasm (arrows) and nuclear picnosis (p) were observed. On the other hand, Chang cells (f) experienced early apoptosis, was indicated by protrusions of the cell membrane (membrane blebbing) (arrowhead), cytoplasmic vacuoles (arrows) and sporadically large perinuclear vacuoles (pv). The morphological studies clearly demonstrated different susceptibility between $\mathrm{SiHa}$ and Chang cells to the identical treatment as well as different mechanism of cell damage for the investigative compound as well as taxol in $\mathrm{SiHa}$ and Chang cell lines although both the compounds $(6 \mathrm{C}$ and taxol) ruptured the cellular monolayer.

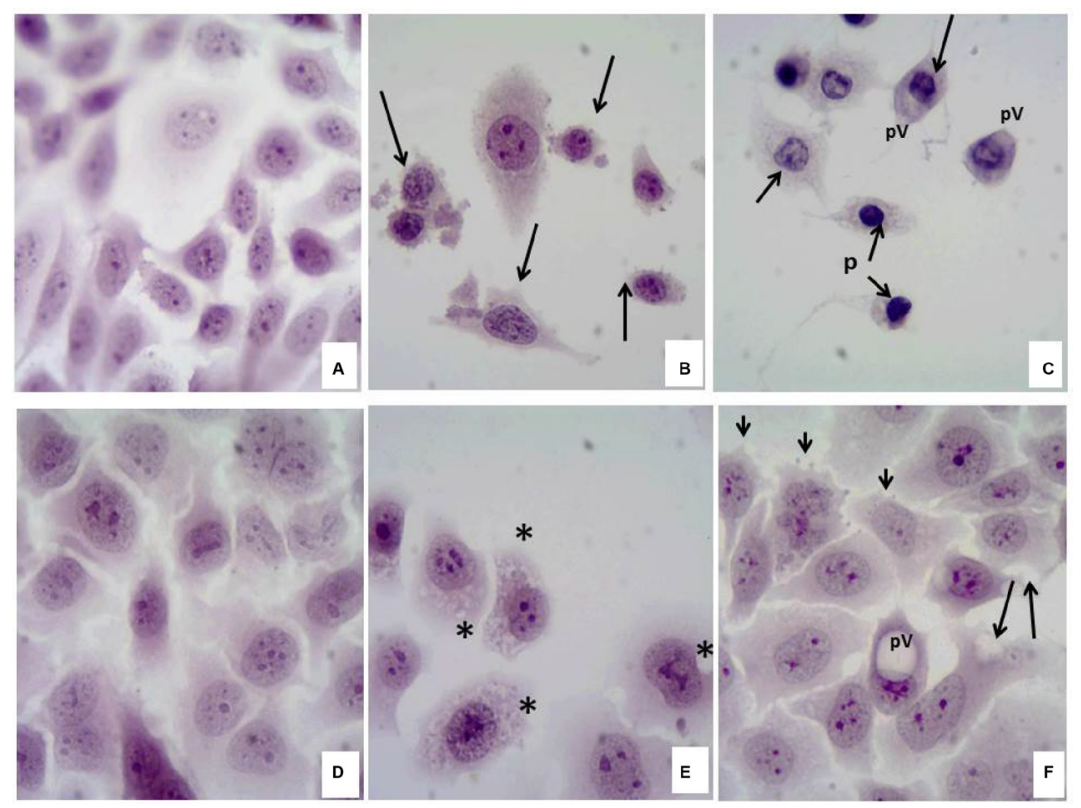

Figure 2: Cytotoxic effect of the compound 6C in SiHa and Chang cells. 
Alternatively, the trans diastereomers exhibited moderate to poor $\left(\mathrm{IC}_{50}: 4.79\right.$ to $>10.00$ in $\mathrm{SiHa}$ and 5.16 to $>10.00$ in B16F10 cell lines) anticancer activity against the tested cancer cell lines as well as in Chang (normal liver) cells (Table 2).

\section{Apoptotic activity}

The cis-diastereomer 6C demonstrated apoptosis in B16F10 cancer cells through caspase-3 activation, was determined by choosing podophyllotoxin (a $\gamma$-lactone bearing pyrogallol derivative) as positive control (Figure 3 ).

\section{DISCUSSION}

It is always challenging to control the diastereoselectivity in $\beta$-lactam synthesis. The cis and trans diastereomers can be identified by the coupling constant values of the protons $\mathrm{H}-3$ and $\mathrm{H}-4$ in the $\beta$-lactam ring $\left(J_{3,4}>4.0 \mathrm{~Hz}\right.$ represents a cis isomer whereas $\mathrm{J}_{3,4}<3.0$ $\mathrm{Hz}$ indicates trans stereoisomer) [18]. As a representative example the ${ }^{1} \mathrm{H}$ NMR spectra of the compounds ( \pm )-trans3-amino-1,4-bis(4-methoxyphenyl)azetidin-2-one (1T) and ( \pm )-cis-3-amino-1,4-bis(4-methoxyphenyl)azetidin-2-one (1C) could be considered (Figure 4). For the compound (1T) the two protons $\mathrm{H}-3$ and $\mathrm{H}-4$ appeared at $3.96 \mathrm{ppm}$ $(J=1.7 \mathrm{~Hz})$ and $4.57 \mathrm{ppm}(J=1.6 \mathrm{~Hz})$ respectively whereas in the compound $(1 \mathrm{C})$, the coupling constant values for both the protons $\mathrm{H}-3$ and $\mathrm{H}-4$ are the same $(J=5.0 \mathrm{~Hz})$. In fact, the diastereoselectivity in $\beta$-lactam formation depends on the generation of zwitterionic intermediate and the extent of conrotatory cyclization (ring-closure) of the intermediate to produce cis or trans $\beta$ lactams [19, 20].

It is well-known that stereochemistry of a drug molecule is greatly responsible for its pharmacological activity. Accordingly, the stereoisomer that produces better

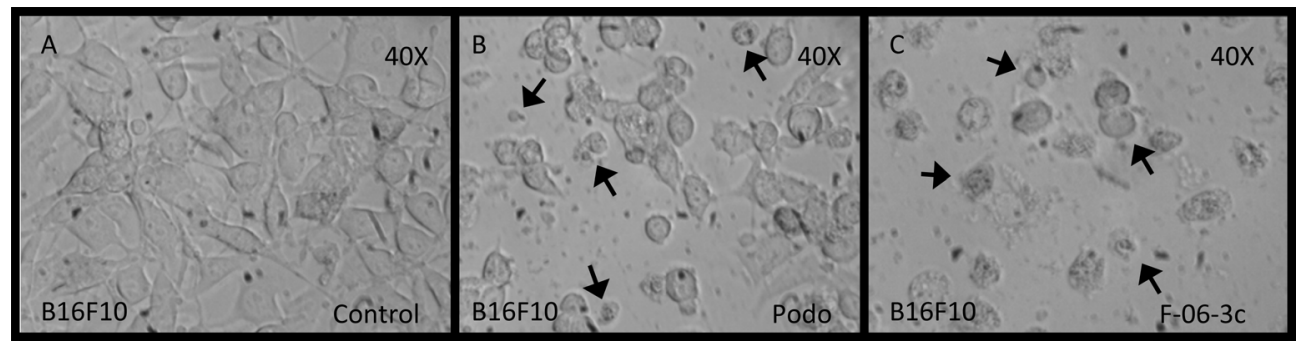

Figure 3: B16F10 cells under conditions of apoptosis with podophyllotoxin and 6C. (A) Control untreated cells, (B) Cells treated with podophyllotoxin, $(\mathbf{C})$ Cells treated with the compound $6 \mathrm{C}$.

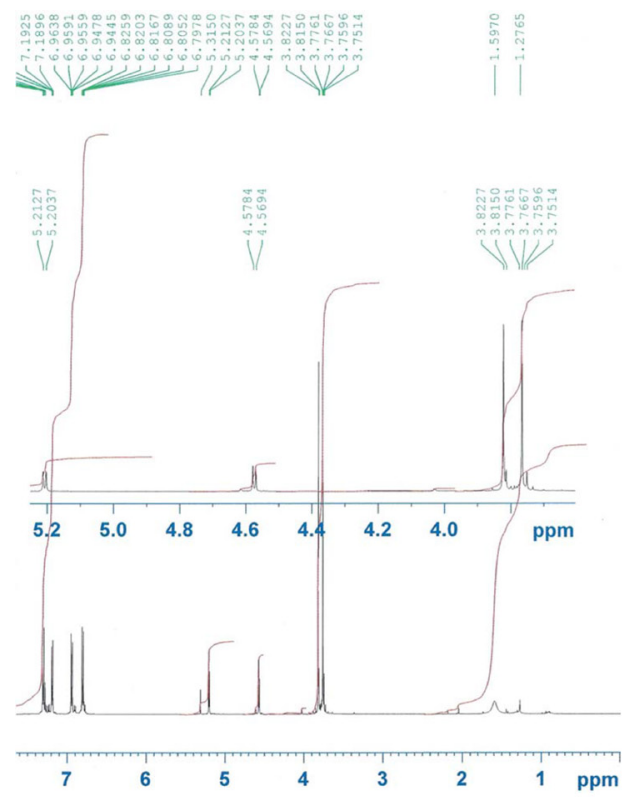

${ }^{1} \mathrm{H}-\mathrm{NMR}$ spectrum of $1 \mathrm{C}$ (Left)
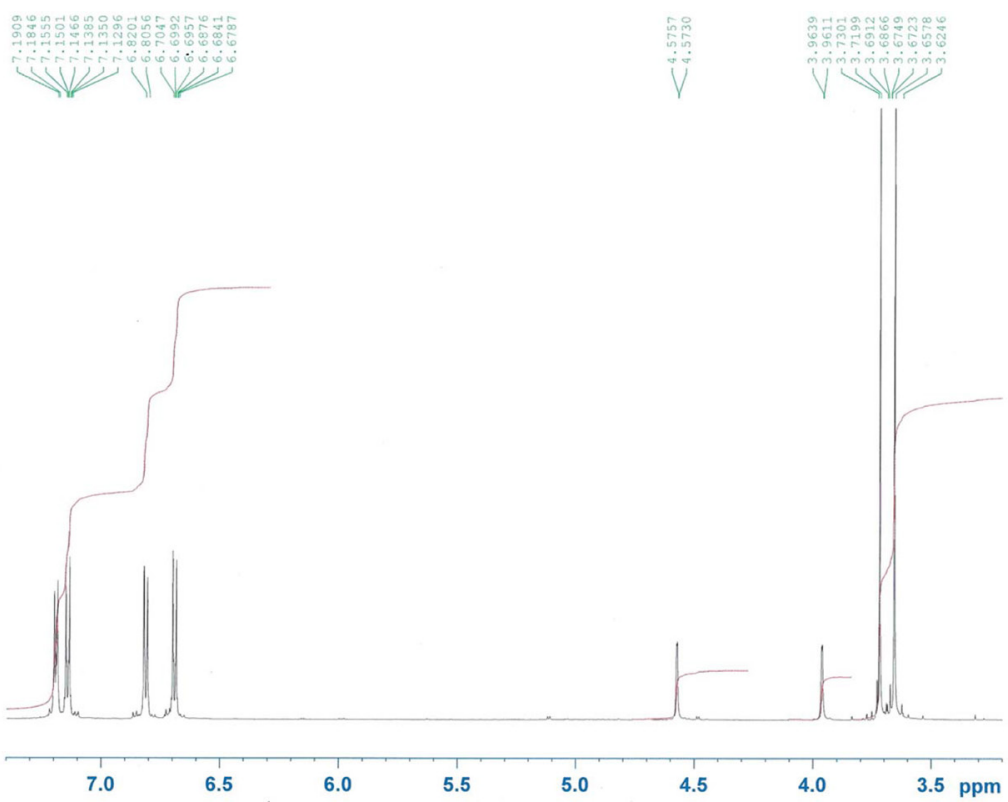

${ }^{1} \mathrm{H}-\mathrm{NMR}$ spectrum of $1 \mathrm{~T}$ (Right)

Figure 4: ${ }^{1} \mathrm{H}$ NMR spectra of $1 \mathrm{C}$ (Left) and $1 \mathrm{~T}$ (Right). 
therapeutic activity is known as eutomer and the less potent (sometimes inactive or even toxic) stereoisomer is known as distomer. The drugability of the newly synthesized terminal $\beta$-lactams (1C-1T and 1T-7T) has been validated by modified 'Rule of 5' (RO5) in Supplementary Table 1. It was found that all the fourteen newly synthesized $\beta$-lactams possess durglikeness and consequently can be termed as possible 'hits'. The in vitro anticancer evaluation has been carried out against $\mathrm{SiHa}$ (human cervical carcinoma), B16F10 (murine melanoma), K562 (human immortalized myelogenous leukemia) and Chang cell lines. It has also been confirmed that the mechanism of anticancer activity was apoptosis-induced cell death. Finally, through a molecular docking analysis, a better and clearer understanding of the plausible $\beta$-lactam- $\beta$-tubulin interaction was explained, considering the protein $\beta$-tubulin as the therapeutic target.

The free energy coupling values for the cis and trans $\beta$-lactams on the proposed target $\beta$-tubulin do not match with that of two widely used natural anticancer drugs taxol and vincristine rather the values match with that of another anticancer alkaloid colchicine. This indicates that the binding sites of the $\beta$-lactams and colchicine are similar in nature. Accordingly, the detail mechanism of action of the $\beta$-lactams might be similar to that of colchicine. The docking score of the compound $6 \mathrm{C}$ is better than the natural drug colchicine (-7.6 compared to -7.4 for colchicine, Table 1) supports better anticancer activity of this compound than colchicine which has been confirmed by in vitro anticancer evaluation (Table 2). The $\mathrm{IC}_{50}$ values of the compound $6 \mathrm{C}$ are better than colchicine against $\mathrm{SiHa}$ and $\mathrm{B} 16 \mathrm{~F} 10$ cancer cell lines. In fact, the drug-protein interactions depend on the chemical nature and three dimensional spatial orientation of the drug molecule and the subsequent interactions with the amino acid residues on the binding sites in $\beta$-tubulin. The molecular interactions of the compound $6 \mathrm{C}$ with $\beta$-tubulin showed bonding interactions with the Cys 239, Lys 252, Val 323, Met 257, Lys 350, Leu 246 and Ala 248 amino acid residues (Figure 1). Based on the accumulated data a strong interaction between the $\beta$-lactam pharmacophore and the aminoacid residues of the $\beta$-tubulin can be proposed.

Interestingly, the compound $6 \mathrm{C}$ showed strong in vitro anticancer activity $\left(\mathrm{IC}_{50}=0.7 \mu \mathrm{M}\right)$ in murine melanoma (B16F10) cell lines and $\mathrm{IC}_{50}=2.34 \mu \mathrm{M}$ in human cervical carcinoma $\mathrm{SiHa}$ cell lines and qualified as the lead with considerable anticancer activity in comparison to colchicine. The trans- $\beta$-lactams $1 \mathrm{~T}, 2 \mathrm{~T}$, 4T, 5T, and the cis- $\beta$-lactams $2 \mathrm{C}, 3 \mathrm{C}, 4 \mathrm{C}$ and $7 \mathrm{C}$ showed good in vitro anticancer activity $\left(\mathrm{IC}_{50}=5-10 \mu \mathrm{M}\right)$ against $\mathrm{SiHa}$ cancer cell lines whereas the $\beta$-lactams 1T, 2T, $5 \mathrm{~T}$ and $4 \mathrm{C}$ demonstrated good in vitro anticancer activity $\left(\mathrm{IC}_{50}=5-10 \mu \mathrm{M}\right)$ against B16F10 cancer cell lines. On the other hand, two compounds $2 \mathrm{C}$ and $3 \mathrm{C}$ showed strong in vitro anticancer activity $\left(\mathrm{IC}_{50}<5 \mu \mathrm{M}\right)$ against $\mathrm{B} 16 \mathrm{~F} 10$ cancer cell lines. Besides the lead compound 6C, two other compounds $1 \mathrm{C}$ and $5 \mathrm{C}$ demonstrated strong in vitro anticancer activity $\left(\mathrm{IC}_{50}=5-10 \mu \mathrm{M}\right)$ against $\mathrm{SiHa}$ and
B16F10 cancer cell lines. Interestingly, two cis-compounds $3 \mathrm{C}$ and $7 \mathrm{C}$ showed good in vitro anticancer activity $\left(\mathrm{IC}_{50}=\right.$ 5-10 $\mu \mathrm{M}$ ) against K562 cancer cell lines. All the fourteen compounds are less toxic (more selective) than the positive control colchicine, a well-known cancer chemotherapeutic agent. In Chang cells 6C showed 10 times lesser toxicity in comparison to the drug colchicine (Table 2).

\section{MATERIALS AND METHODS}

\section{Chemistry}

Melting points were determined in a Fisher Scientific electrochemical Mel-Temp* manual melting point apparatus (Model 1001) equipped with a $300^{\circ} \mathrm{C}$ thermometer. FT-IR spectra were recorded on a Bruker Alpha modular Platinum-ATR FT-IR spectrometer with OPUS software, using the samples directly (neat) without making pallets. ${ }^{1} \mathrm{H}$ NMR $(600 \mathrm{MHz})$ and ${ }^{13} \mathrm{C} \mathrm{NMR}$ $(150 \mathrm{MHz})$ spectra were obtained at room temperature with Bruker superconducting Ultrashield Plus 600 $\mathrm{MHz}$ NMR spectrometer with central field $14.09 \mathrm{~T}$, coil inductance $89.1 \mathrm{H}$, and magnetic energy $1127.2 \mathrm{~kJ}$ using $\mathrm{CDCl}_{3}$ as solvent. All the solvents were purchased from Fisher-Scientific throughout the investigation. Dichloromethane and triethylamine were dried following the standard procedures. Deionized water was used for the preparation of all aqueous solutions.

\section{General procedure for the synthesis of imines}

Amine and aldehyde were mixed in equimolar (1:1) ratio and refluxed in dry toluene using a Dean-Stark water separator. After completion of the reaction (monitored by thin layer chromatography, 2-3 hours), the solvent was removed under reduced pressure distillation (by rotavapor) and the pure imine was isolated by crystallization from dichloromethane/hexanes.

\section{General procedure for the synthesis of 3-phthalimido $\beta$-lactams via the Staudinger reaction}

A representative experimental procedure is described as follows: A solution of phthalimidoacetic acid ( $N$-phthaloylglycine) (1.5 mmol) in anhydrous dichloromethane $(10 \mathrm{~mL})$ was added (dropwise during 30 minutes) to another solution consisted of 2-chloro-1methylpyridinium iodide (Mukaiyama reagent, $3 \mathrm{mmol}$ ) and triethylamine $(6 \mathrm{mmol})$ in $10 \mathrm{~mL}$ dry dichloromethane at 0 to $(-5)^{\circ} \mathrm{C}$ temperature under inert (argon) atmosphere. This mixture was stirred for 2 hours maintaining the same temperature. Imine $(1 \mathrm{mmol})$ in dry dichloromethane (10 $\mathrm{mL}$ ) was then added to this mixture at the same temperature. The reaction mixture was then stirred overnight at room temperature and monitored by thin layer chromatography 
(TLC). After completion of the reaction, the reaction mixture was washed with saturated sodium bicarbonate solution $(10 \mathrm{~mL})$, brine $(10 \mathrm{~mL})$ and deionized water successively. The organic layer was dried over anhydrous sodium sulfate, filtered and evaporated to obtain the crude product. Column chromatography over silica gel was performed using ethyl acetate/hexanes mixtures to isolate the cis- and trans-3-phthalimido $\beta$-lactams in pure form. The cis:trans ratio was approximately $2: 1$ in all the cases.

\section{General procedure for the synthesis of 3-amino $\beta$-lactams from 3-phthalimido $\beta$-lactam}

Ethylenediamine ( $2 \mathrm{mmol}$ ) was added to a solution of diastereomerically pure 3-phthalimido $\beta$-lactam $(1 \mathrm{mmol})$ in anhydrous ethyl alcohol $(5 \mathrm{~mL})$ under argon atmosphere. This mixture was stirred at room temperature and the progress of the reaction was monitored by TLC. After completion of the reaction (15 min-1 h) the ethanol was removed by reduced pressure distillation and the crude mass was extracted with ethyl acetate $(25 \mathrm{~mL})$. The ethyl acetate layer was washed with brine and water successively $(10 \mathrm{~mL})$, and dried over anhydrous sodium sulfate. The pure products were obtained via column chromatography over silica gel using ethyl acetate/hexanes as the eluent.

\section{Molecular docking}

One of the major cancer related proteins, $\beta$-tubulin, was considered as the theoretical target to perform docking studies of the azetidin-2-ones ( $\beta$-lactams) as possible antiproliferative compounds. The hydrogens and charges on receptor and ligand were assigned with the Chimera program [21]. The pdbqt files for docking simulations were generated using the AutoDock Tools interface. The docking of azetidine-2-one derivatives on $\beta$-tubulin was performed with Autodock 4.2 program [22]. The grid sizes in each dimension ( $\mathrm{x}, \mathrm{y}$, and $\mathrm{z}$ ) were $60 \AA$, grid points separated by $0.375 \AA$, with its center in 116,89 and 6 for $\mathrm{x}, \mathrm{y}$ and $\mathrm{z}$, respectively. The analysis of AutoDock predicted molecular interactions was conducted by AutoDock vina interface and Chimera program. Maestro software showed the key amino acids from colchicine binding site of $\beta$-tubulin.

\section{Biology}

\section{Cytotoxic activity}

In vitro anticancer assays were performed in triplicate for the determination of mean values. The human cervical carcinoma $\mathrm{SiHa}$, murine melanoma B16F10, chronic myelogenous leukemia (CML) K562, and Chang cell lines were cultured in minimum essential medium of Eagle at $37{ }^{\circ} \mathrm{C}$ in a $95 \% \mathrm{O}_{2} / 5 \% \mathrm{CO}_{2}$ atmosphere with $10 \%$ fetal bovine serum, $2 \mathrm{mM}$ L-glutamine and
$1 \%$ penicillin/streptomycin. Cells were trypsinized and seeded at a density of $5 \times 10^{4}$ cells $/ \mathrm{mL}$ in a 96 -well plate and incubated at $37{ }^{\circ} \mathrm{C}, 95 \% \mathrm{O}_{2} / 5 \% \mathrm{CO}_{2}$ atmosphere for $24 \mathrm{~h}$. Thereafter the cells were treated with azetidin-2-one derivatives (dissolved in DMSO) at various concentrations between $312 \mathrm{nM}-10 \mu \mathrm{M}$, and re-incubated for further $72 \mathrm{~h}$. Wells containing the equal volume of the vehicle DMSO $(1 \% \mathrm{v} / \mathrm{v})$ were used as background (negative control). The culture medium was then removed and the cells washed with $100 \mu \mathrm{L}$ phosphate buffered saline (PBS); then $10 \mu \mathrm{L}$ WST-1 (Roche, USA) was added. Cells were incubated for $2 \mathrm{~h}$ in absence of light at $37^{\circ} \mathrm{C}$, and absorbance was read subsequently [23]. The absorbance value of cells without added compound was set to $100 \%$ cell viability and was compared versus cell death density (cells treated with Triton $\times 100$ ) and also natural anticancer drug colchicine as positive control compound. Afterwards, these values were used to assess half maximal inhibitory concentration $\left(\mathrm{IC}_{50}\right)$ using Graph-Pad Prism software.

\section{Hematoxylin/Eosin staining of the cells}

Cells $\left(10 \times 10^{4}\right)$ were grown on coated poly-lysine coverslips which were placed in 6-well microplates overnight and then incubated for $24 \mathrm{~h}$ in the presence of compound $6 \mathrm{C}$ or taxol, subsequently stained with hematoxylin and eosin. Coverslips were then observed by Light microscopy of bright field (40X).

\section{Apoptotic activity}

The mechanism of cell death was identified as apoptosis. It was validated with the compound $6 \mathrm{C}$. Enzyme activity associated with the induction of apoptosis was determined by caspase- 3 assay (Invitrogen, USA) as described in the protocol [24]. A concentration of approximately $3 \times 10^{6}$ cells $/ \mathrm{mL}$ (B16F10) was taken and incubated for $24 \mathrm{~h}$ at $37^{\circ} \mathrm{C}$ in $5 \% \mathrm{CO}_{2}$ environment. Podophyllotoxin (apoptosis inducing agent) was used as positive control. After incubation for $24 \mathrm{~h}$ the cells were re-suspended and $50 \mu \mathrm{L}$ of cell lysis reagent was added, then cells were incubated for $10 \mathrm{~min}$ in ice bath and centrifuged. The supernatant (cytosol extract) was transferred into a new effendrof. Cytosol extract was diluted with cell lysis reagent to a concentration of $2 \mu \mathrm{g} / \mu \mathrm{L}$, in a total volume of $50 \mu \mathrm{L}$. Then $50 \mu \mathrm{L}$ of $2 \mathrm{X}$ reaction buffer and $5 \mu \mathrm{L}$ of tetrapeptide- $p$-nitroaniline (DEVD- $p$ NA) were added. It was incubated at $37^{\circ} \mathrm{C}$ for $2 \mathrm{~h}$ (in dark), and finally the optical density at $405 \mathrm{~nm}$ was measured with an ELISA Reader [24]. Caspase-3 activity was calculated that confirmed apoptosis as the mechanism of cell death. With this data and the value of caspasae-3 induction by the podophyllotoxin, it was possible to calculate the ratio of apoptosis with respect to the positive control on murine melanoma cancer cells (B16F10). 


\section{CONCLUSIONS}

In conclusion, a series of fourteen (seven pairs of cis- and trans-diastereomers) diversely substituted diastereomeric $\beta$-lactam derivatives have been successfully synthesized. In vitro anticancer evaluation showed that one of these newly synthesized $c i s-\beta$-lactam derivatives (6C) possesses higher potency in human cervical carcinoma $\mathrm{SiHa}$ cell lines, six times higher potency in murine melanoma B16F10 cell lines and 10 times less toxicity in normal liver Chang cell lines compared to the positive control colchicine, a well-known anticancer alkaloid. Besides the cis- $\beta$-lactam $6 \mathrm{C}$, most of the newly synthesized $\beta$-lactams (both diastereomers) exhibited moderate to strong anticancer activity against $\mathrm{SiHa}$ and B16F10 cancer cell lines. The binding sites of the compound on $\beta$-tubulin was found to be similar with that of colchicine and apoptotic cell death through caspase activation was found as the mechanism of action. It was supported by the microscopic observation. Molecular coupling of the compound $6 \mathrm{C}$ on $\beta$-tubulin colchicine site, exhibited binding interactions with the Cys 239, Lys 252, Val 323, Met 257, Lys 350, Leu 246 y Ala 248 amionacid residues by molecular docking assay. The molecule $6 \mathrm{C}$ may find its application in anticancer drug discovery process.

\section{ACKNOWLEDGMENTS AND FUNDING}

The authors are thankful to the Kleberg Foundation of Texas for funding (to DB). Thanks are accorded to the University of Texas Rio Grande Valley and Universidad Autónoma de Nuevo León for providing laboratory/ infrastructural facilities. FOS thanks to CONACYT for a scholarship (No. 419250). The Department of Chemistry at the University of Texas Rio Grande Valley is grateful for the generous support provided by the Robert A. Welch Foundation (Grant No. BX-0048).

\section{CONFLICTS OF INTEREST}

None.

\section{Dedication statement}

A heartfelt tribute to the memory of Professor Asima Chatterjee, the legendary scientist-teacher-humanitarian, on the occasion of her birth centenary (1917-2017).

\section{REFERENCES}

1. World Health Organization Cancer fact sheets: http://www. who.int/mediacentre/factsheets/fs297/en/ (Accessed on January 30, 2017).
2. Bandyopadhyay D. Farmer to pharmacist: curcumin as an anti-invasive and antimetastatic agent for the treatment of cancer. Front Chem. 2014; 2:113.

3. Bandyopadhyay D. Curcumin: A folklore remedy from kitchen on the way to clinic as cancer drug In Horizons in Cancer Research, 2014, Nova Science Publishers, Inc., Hauppauge, New York, USA.1-42.

4. Bandyopadhyay D, Rhodes E, Banik BK. A green, chemoselective, and practical approach toward $\mathrm{N}$-(2azetidinonyl) 2,5-disubstituted pyrroles. RSC Adv. 2013; 3:16756-16764.

5. Bandyopadhyay D, Cruz J, Yadav RN, Banik BK. An expeditious iodine-catalyzed synthesis of 3-pyrrole-substituted 2-azetidinones. Molecules. 2012; 17:11570-11584.

6. Bandyopadhyay D, Cruz J, Banik BK. Novel synthesis of 3 -pyrrole substituted $\beta$-lactams via microwave-induced bismuth nitrate-catalyzed reaction. Tetrahedron. 2012; 68:10686-10695.

7. Dawra N, Ram RN. An efficient method for the synthesis of some chlorinated and heteroatom rich triazole-linked $\beta$-lactam glycoconjugates. Tetrahedron. 2016; 72:7982-7991.

8. Banik BK, Banik I, Becker FF. Asymmetric synthesis of anticancer $\beta$-lactams via Staudinger reaction: Utilization of chiral ketene from carbohydrate. Eur J Med Chem. 2010; 45:846-848.

9. Banik BK, Samajdar S, Becker FF. Asymmetric synthesis of anticancer $\beta$-lactams via Staudinger reaction. Mol Med Rep. 2010; 3:319-321.

10. Banik BK, Becker FF. Selective anticancer activity of $\beta$-lactams derived from polyaromatic compound. Mol Med Rep. 2010; 3:315-316.

11. Bandyopadhyay D, Rivera G, Salinas I, Aguilar H, Banik BK. Remarkable iodine-catalyzed synthesis of novel pyrrole-bearing $N$-polyaromatic $\beta$-lactams. Molecules. 2010; 15:1082-1088.

12. O'Boyle NM, Carr M, Greene LM, Bergin O, Nathwani SM, McCabe T, Lloyd DG, Zisterer DM, Meegan MJ. Synthesis and evaluation of azetidinone analogues of Combretastatin A-4 as tubulin targeting agents. J Med Chem. 2010; 53:8569-8584.

13. Patel AB, Chikhalia KH, Kumari P. Study of new $\beta$-lactamssubstituted s-triazine derivatives as potential bioactive agents. Med Chem Res. 2015; 24:468-481.

14. Galletti P, Soldati R, Pori M, Durso M, Tolomelli A, Gentilucci L, Dattoli SD, Baiula M, Spampinato S, Giacomini D. Targeting integrins $\alpha \mathrm{v} \beta 3$ and $\alpha 5 \beta 1$ with new $\beta$-lactam derivatives. Eur J Med Chem. 2014; 83:284-293.

15. O'Boyle NM, Carr M, Greene LM, Keely NO, Knox AJS, McCabe T, Lloyd DG, Zisterer DM, Meegan MJ. Synthesis, biochemical and molecular modeling studies of antiproliferative azetidinones causing microtubule disruption and mitotic catastrophe. Eur J Med Chem. 2011; 46:4595-4607.

16. Staudinger H. Zur Kenntniss der Ketene. Diphenylketen. Justus Liebigs Ann Chem. 1907; 356:51-123. 
17. Mukhtar E, Adhami VM, Mukhtar H. Targeting microtubules by natural agents for cancer therapy. Mol Cancer Ther. 2014; 13:275-284.

18. Jarrahpour A, Zarei M. Efficient one-pot synthesis of 2-azetidinones from acetic acid derivatives and imines using methoxymethylene- $N, N$-dimethyliminium salt. Tetrahedron. 2010; 66:5017-5023.

19. Banik BK, Becker FF, Banik I. Synthesis of anticancer $\beta$-lactams: mechanism of action. Bioorg Med Chem. 2004; 12:2523-2528.

20. Banik BK, Banik I, Becker FF. Stereocontrolled synthesis of anticancer $\beta$-lactams via the Staudinger reaction. Bioorg Med Chem. 2005; 13:3611-3622.

21. Yang Z, Lasker K, Schneidman-Duhovny D, Webb B, Huang CC, Pettersen EF, Goddard TD, Meng EC, Sali A,
Ferrin TE. UCSF Chimera, MODELLER, and IMP: An integrated modeling system. J Struct Biol. 2012; 179:269-278.

22. Trott O, Olson AJ. AutoDock Vina: Improving the speed and accuracy of docking with a new scoring function, efficient optimization, and multithreading. J Comput Chem. 2010; 31:455-461.

23. Berridge MV, Tan AS, McCoy KD, Wang R. The biochemical and cellular basis of cell proliferation assays that use tetrazolium salts. Biochemica. 1996; 4:14-19.

24. Mazumder S, Plesca D, Almasan A. Caspase- 3 activation is a critical determinant of genotoxic stress-induced apoptosis. Methods Mol Biol. 2008; 414:13-21. 